\title{
Referans Evapotranspirasyonun Mekansal Değișiminin Belirlenmesinde Gediz Havzası Örneği
}

\author{
Yusuf Ersoy YILDIRIM' ID IIsmail TAȘ \\ 'Ankara Üniversitesi Ziraat Fakültesi Tarımsal Yapılar ve Sulama Bölümü, Ankara \\ ${ }^{2 *}$ Çanakkale Onsekiz Mart Üni. Ziraat Fak. Tarımsal Yapılar ve Sulama Bölümü. Çanakkale \\ ${ }^{3}$ Tarla Bitkileri Merkez Araștırma Enstitüsü, Ankara
}

\begin{abstract}
*Sorumlu yazar e-mail (Corresponding author e-mail): tas_ismail@yahoo.com
Geliș tarihi (Received):

Kabul tarihi (Accepted):
\end{abstract}

DOI: $10.21657 /$ topraksu.655582

\section{Öz}

Coğrafi Bilgi Sistemleri (CBS), dünyadaki özellikleri ve olayları haritalamak ve analiz etmek için son derece yararlı ve kullanıșlı bilgisayar tabanlı araçlardır. CBS teknolojisi, sorgulama, analiz etme, istatistiksel değerlendirme, ortakveritabanı ișlemlerini gerçekleștirerek coğrafianalizlerveharitalaryapma, çalıșmalara görsellikler katmak gibi bir çok avantaja sahiptir. Klasik yöntemlerle Evapotranspirasyon haritalarının hazırlanması havzanın büyüklüğüne göre aylar hatta yıllar alabilmektedir. Ancak son yıllarda gelișen teknolojiye paralel olarak zaman intiyacı azalmıș hatta dakikalar içinde söz konusu haritalar yapılabilir hale gelinmiștir. Jeoistatistiksel metotlar büyük alanların kısa sürede haritalanmasında yaygın olarak kullanılmaktadır. Gediz havzasını kapsayan bu çalıșmada, havzada bulunan uzun yıllık iklim verilerinde yararlanılarak Referans Evapotranspirasyon (ETo) değerleri Standardize FAO Penman Montehit yöntemi ile hesaplanmıștır. Hesaplamada 6 tanesi havza içinde 8 tanesi de havza dıșı komșu istasyon değerleri kullanılııı̦tır. Hesaplamalar sonucunda, Nisan, Mayıs, Haziran, Temmuz, Ağustos, Eylül ve yıllık toplam ETo değerleri jeoistaitisitik yöntemiyle haritalanmıștır. Jeoistatistik haritaların üretilmesinde enterpolasyon yöntemi olarak cokriging, semivariogram olarak da spherical model kullanıımıștır. ETo haritalarının hazırlanmasında söz konusu yöntem ve model güvenilir șekilde kullanılabileceği belirlenmiștir.

Anahtar kelimeler : Gediz Havzası, jeoistatistik, referans evapotranspirasyon

\section{Determination of Spatial Variation of Reference Evapotranspiration Case Study of Gediz Basin}

\footnotetext{
Abstract

Geographic Information Systems (GIS) are computer based tools for mapping and analysing features and events on earth. GIS technology integrates common database operations such as query and statistical analysis with the unique visualisation and geographic analysis benefits offered by maps Evapotranspiration mapping with classical methods may take months and even years based on the size of the area to be mapped. However, recently developed methods decreased the time consumed for such mapping practices to minutes. Geostatistical methods are the most commonly used methods for mapping over large areas in a short time. In present study, Reference Evapotranspiration (ETo) values were calculated by Standardize FAO Penman Montehit method using long-term climate data in the
} 
Gediz basin. The calculated ETo values were mapped for April, May, June, July, August, September and yearly total by using geoistitic method. It was used 6 station in basin and 8 station out of basins for calculation. In the production of geostatistics maps, cokriging was used as interpolation method and spherical model was used for model of semivariogram. At the end of the study, it was determined that ETo maps could be produced with reliable method and model.

Key words: Gediz Basin, geostatistic, reference evapotranspiration

\section{Giriș}

Dünyanın tamamında su kısıtlılı̆ı en önemli sorunların bașında yer almaktadır. Tüm faaliyetler suyun miktarı ve kalitesine bağlıdır. Temiz su kaynaklarına olan talebin gün geçtikçe artması beraberinde su kaynağı olarak kullanılabilecek kaynakların dikkatli bir șekilde incelenmesi ve değerlendirilmesini de beraberinde getirmektedir.

Bitki su tüketim değerleri, gerek sulama projelerinin gerekse sulama programlarının hazırlanmasında, hayati öneme sahiptir. Bitki su tüketimi kolay ölçülen bir parametre değildir. Bunu belirleyebilmek için özel aletlerle doğru șekilde ölçülen çeșitli fiziksel parametreler yanında lizimetrelere intiyaç vardır. Lizimetre kullanımı, yoğun emek isteyen pahalı bir yöntem olmasının yanında ölçümlerin doğru bir șekilde yapılabilmesi ve sistemin tam anlamılya ișletilebilmesi için ișlemlerin konu uzmanı eğitimli araștırmacı personel tarafından gerçekleștirilmesi gereklidir. Sıradan ölçümler için uygun olmamasına karșın dolaylı metotlarla tahmin edilen su tüketimi değerlerini kıyaslanması için söz konusu yöntem önemini sürdürmektedir (Allen vd. 1998).

Bitkisel üretimde yüksek kalite ve verim için en önemli girdi sulama suyudur. Bitkinin gereksinim duyduğu suyun, ihtiyaç duyulan zamanda ve miktarda sağlanabilmesi ancak doğru verilerle tasarlanmıș, inșa edilmiș ve ișletilen sistemlerde mümkündür. Sulama yapılarının planlama ve tasarım çalıșmalarının en önemli bileșenlerinden bir tanesi de inșaatın gerçekleștirileceği bölgedeki üretilen ve üretilmesi planlanan bitkilerin su tüketim değerlerinin bilinmesidir. Tasarımda dikkate alınan bitki su tüketim değerlerinin doğruluğu, doğrudan planlanan sonuçlarını etkiler (Taș ve Kırnak, 2011 ).

Jeoistatistik, gelișen teknolojiye bağlı olarak çok daha az emek ve masrafın yanında çok daha kısa sürelerde incelenen parametrelerin kendi aralarındaki ve mekansal değișimlerindeki ilișkileri ortaya koyan tekniktir. Çok farkı bilim dallarında uygulama alanı bulan jeoistatistik ile araștırılan değișkenin örnek alınmayan noktalardaki değerleri tahmin edilerek ve bu değișkene ait tahmin haritaları olușturularak hazırlanan haritaların daha doğru ve güvenilir olmasını sağlamaktadır.

Sulama planlaması, sulama zamanının ve miktarının belirlenmesine yönelik farklı iș ve ișlemleri içerir. Bu amaç için hesaplanan referans ETo, tahmini olarak bitki su gereksiniminde kullanılmaktadır. Bölgesel düzeyde evapotranspirasyonunun niceliksel olarak bilinmesi; yetiștirilecek ürün, verim, kalite, su kaynaklarının en uygun șekilde kullanımı, yönetimi ve çevresel değerlendirmeler gibi amaçlar için gereklidir. Önemli topoğrafik varyasyonları olan bölgelerde, yükseklik etkisinin buharlașma ısısı üzerindeki etkisi de enterpolasyon için dikkate alınmalıdır. Bu nedenle dağlık alanlarda Ordinary kriging, regresyon kriging ve cokriging gibi jeostatistik enterpolasyon yöntemleri uygulanmaktadır (Martinez-Cob ve Cuenca, 1992; Philips vd., 1992). Jeoistatisitksel yöntemlerin performansları, çalıșılan değișkene, verinin mekansal konfigürasyonuna, kullanılan varsayımlara ve kesinliklerine bağlı olduğu için șimdiye kadar belirli bir enterpolasyon yönteminin üstünlüğü açık bir șekilde belirlenememiștir. (Creutin ve Obled, 1982; Weber ve England, 1994). Bu nedenle her bir enterpolasyon yöntemi sadece bazı özel durumlar için en iyi yöntem olabilir (Isaaks ve Srivastava 1989). íki değișken arasındaki korelasyonun doğası hakkında herhangi bir varsayım yapılmadığı durumda, Cokriging'in teorik temellerinin ve dayanağının daha iyi olmasından dolayı, verilerin korelasyon derecesi ve mekansal yapısı çapraz semivariogramda dikkate alınır (Ahmed ve De Marsily, 1987). Bununla birlikte, kodlama için hesaplama gereklilikleri yüksek olduğundan, regesyon kriging yöntemi daha basit bir alternatif olarak değerlendirilebilir (Samper ve Carrera, 1990). 
Noshadi ve Sepaskhah, (2005)'in ETo'ın kestirimine yönelik olarak yaptıkları çalıșmada, enterpolasyon yöntemi olarak ordinary kriging, residual kriging ve cokriging yöntemlerini; semivariogram olarak spherical, exponential, Gaussian ve linear-sill yöntemlerini karșılatırmıșlardır. Calıșma sonunda, enterpolasyon yöntemi olarak Cokirigin, semivariogram olarak spherical modelinin ETo haritalamasında kullanılmasını önermișlerdir.

Yapılan bu çalıșmada, günlük meteorolojik verilerden yararlanarak Gediz havzasının Nisan, Mayıs, Haziran, Temmuz, Ağustos ve Eylül aylarının, aylık ve yıllık toplam referans evapotrasnpirasyon değerleri Standardize FAO Penman Montehit yöntemi kullanılarak hesaplanmıștır. Elde edilen değerlerden yararlanılarak Gediz havzasının hem söz konusu aylar için hem de yıllık toplam hesaplanan ETo değerleri, cokriging enterpolasyonyöntemi ve spherical semivariogram modeli kullanılarak jeoistatistiksel yaklașımla ETo haritaları hazırlanmıștır.

\section{MATERYAL VE YÖNTEM}

\section{Çalıșma alanı ve toprak özellikleri}

Gediz Havzası Türkiye'nin batısında Ege Bölgesinde yer alan, sularını Gediz ve kolları vasıtasıyla Ege Denizine boșaltan, Ege, Susurluk ve Küçük Menderes Havzaları arasındaki sahayı

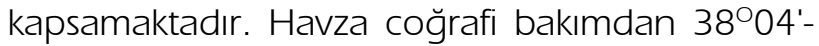

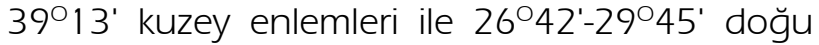
boylamları arasında yer almaktadır. Gediz havzası 17220 km²'lik bir alana sahip olup, Türkiye'nin en büyük nehir havzalarından biridir (Șekil 1). Gediz nehrinin uzunluğu yaklașık 276 km'dir. Havza yükseklikleri, deniz seviyesi ile 2300 m arasında değișmekte ve havzada Marmara gölü, çok amaçlı kullanılan Demirköprü rezervuarı ve sulama amaçlı bazı küçük gölet ve barajlar bulunmaktadır.

Havzada tespit edilmiș 11 Büyük Toprak Grubunun en yaygın olan Kireçsiz Kahverengi Orman toprağı \%28.27'lik bir orana sahiptir. Onları sırasıyla \%17.57 ile Kahverengi Orman toprakları \% 12.93 ile Kireçsiz Kahverengi topraklar, $\% 9.63$ ile Rendzinalar izlemektedir. Alüvyal

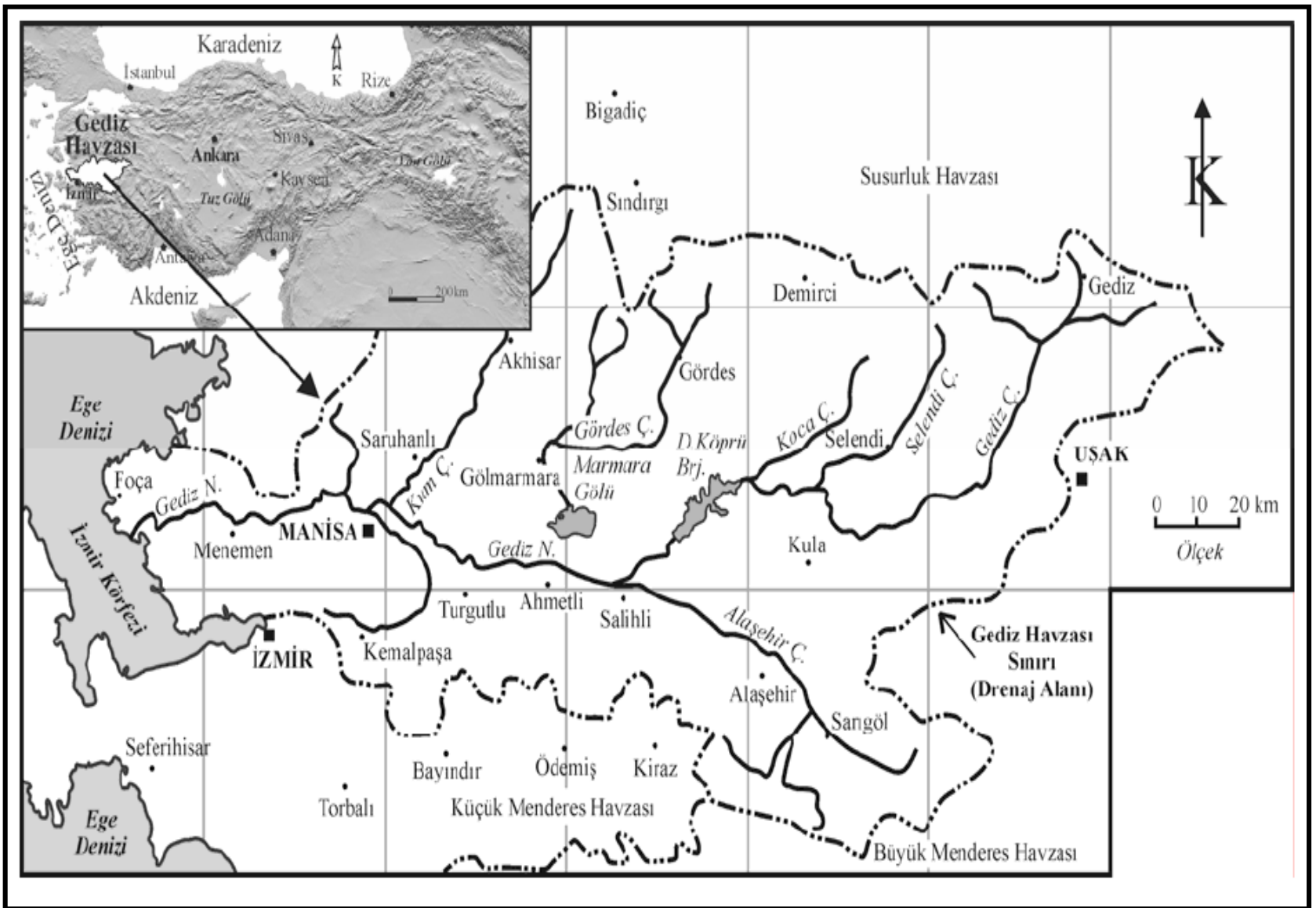

Șekil 1. Gediz havzasının coğrafik konumu

Figure 1. Geographical location of Gediz basin 
topraklar \%10.33, Kırmızı Akdeniz toprakları \%4.06 ve Kolüvyal topraklar \% 5.87 oranındadır. Kestanerengi topraklar \%1.93, Regosoller \%3.15 ve Yüksek Dağ Çayırı toprakları \%0.11'lik alanlara sahiptirler. Ayrıca havzada çıplak kayalıklar, ırmak tașkın yatakları ve kıyı kumulları da \%1.52'lik bir alan kaplamaktadırlar (Anonim, 2003).

\section{Araștırma yerinin iklim özellikleri}

Ege Bölgesi içinde geniș bir alanı kapsayan Gediz Havzası'nda, Akdeniz iklimi ile beraber İç Anadolu'nun karasal iklim özellikleri egemendir. Ovalar ve ovaları çevreleyen vadilerde, karasal nitelikli Akdeniz iklimi görülürken, yüksek dağılk bölgeler ve platolar ile kuzey ve kuzey doğusundaki dağlar ve platolarda İç Anadolu'nun karasal nitelikli ikliminin etkileri görülür. Ovaların çevresindeki dağlar, deniz etkisini kesecek kadar yüksek olmadığından ve denize dik konumlarından dolayı denizin etkisi batıdan doğuya doğru azalan ölçüde hissedilir. Ovalık kesimlerin ikliminde denize yakınlık nedeniyle yumușama söz konusudur.
Yaz aylarında sıcaklık yükselirken, yağıșlar kıș aylarında yoğunlașır.

Uzun yıllar kaydedilen ortalama yağıș, dağlık bölgede yaklașık 800 mm ile Ege sahil bölgesinde yaklașı 500 mm arasında değișmektedir. Ortalama sıcaklıklar $13.5^{\circ} \mathrm{C}-16.6^{\circ} \mathrm{C}$ arasında değișmektedir. Gediz havzasında yer alan bazı Meteoroloji istasyonlarına ait uzun yıllar (19752010) ortalama sıcaklık ve ortalama toplam yağıș miktarları Çizelge 1'de verilmiștir. Söz konusu veriler dikkate alındığında, havzanın yıllık ortalama sıcaklığı $15.9^{\circ} \mathrm{C}$, yıllık ortalama yağıș $446.2 \mathrm{~mm}$ ve yıllık ortalama buharlașma ise 1317.3 mm'dir.

\section{Araștırma yerinin su kaynakları}

Batı Anadolu'da bulunan Gediz Havzası, Ege Denizi, Küçük Menderes ve Bakırçay havzaları arasında yer almaktadır. Havza kuzey, güney ve doğudan yükseklikleri 2000 metreyi bulan dağlar, batıda da Ege Denizi tarafından çevrelenmiștir. Nehrin ana kollarını Deliniș, Selendi, Demirci, Nif, Alașehir ve Kumçay akarsuları olușturur. Bunun

Çizelge 1. T1 ve T2 konularına ait hesaplanan kök yüzdeleri (\%) ve toprak katmanlarındaki tuzluluk değerleri (dS $\left.\mathrm{m}^{-1}\right)$ Table 1. Analysis of Variance for Grain Nitrogen, Zinc and Iron Concentrations and Grain Yield Values

\begin{tabular}{|c|c|c|c|c|c|c|c|c|c|c|c|c|c|}
\hline \multirow{2}{*}{ İstasyon } & \multicolumn{12}{|c|}{ Ortalama Sicaklık $\left({ }^{\circ} \mathrm{C}\right)$} & \multirow{2}{*}{ Ort. / Top. } \\
\hline & 1 & II & III & IV & V & VI & VII & VIII & IX & $x$ & $\mathrm{XI}$ & XII & \\
\hline Akhisar & 6.1 & 7.1 & 9.9 & 14.5 & 19.8 & 24.7 & 27.2 & 26.8 & 22.5 & 17 & 11 & 7.5 & 16.2 \\
\hline Alașehir & 6.3 & 7.9 & 11.1 & 15.3 & 21.2 & 25.8 & 28.2 & 28.2 & 22 & 17 & 12.7 & 8.5 & 17.0 \\
\hline Demirci & 3.7 & 3.9 & 6.6 & 11.3 & 16.9 & 21.2 & 24 & 24.2 & 19.5 & 15 & 9.5 & 5.2 & 13.4 \\
\hline Gediz & 2.4 & 3.3 & 6.5 & 11.1 & 16.2 & 20.7 & 24.1 & 23.8 & 18.9 & 13.2 & 7.4 & 3.9 & 12.6 \\
\hline İzmir & 8.9 & 9.4 & 11.8 & 16 & 20.9 & 25.8 & 28.1 & 27.6 & 23.6 & 18.9 & 13.8 & 10.3 & 17.9 \\
\hline Köprübașı & 4.7 & 6.6 & 9.7 & 14.1 & 20.4 & 25.7 & 28.7 & 28.7 & 21.7 & 16.2 & 11 & 7.0 & 16.2 \\
\hline Manisa & 6.7 & 7.9 & 10.7 & 15.3 & 20.6 & 25.7 & 28.2 & 27.8 & 23.4 & 17.9 & 11.9 & 8.1 & 17.0 \\
\hline Turgutlu & 6.6 & 7.4 & 10.4 & 15.3 & 20.6 & 25.4 & 27.6 & 27.2 & 23.1 & 17.7 & 11.7 & 7.6 & 16.7 \\
\hline \multicolumn{14}{|c|}{ Yağıș (mm) } \\
\hline Akhisar & 79.6 & 77.6 & 64.6 & 49.9 & 33.3 & 10.9 & 4.4 & 4.3 & 17.2 & 43 & 79 & 97.4 & 561.2 \\
\hline Alașehir & 0 & 0 & 0 & 0 & 0 & 0 & 0 & 0 & 0 & 0 & 0 & 0 & 0 \\
\hline Demirci & 72.5 & 80.2 & 69.3 & 62.1 & 41.2 & 14 & 8.5 & 11 & 20.9 & 45.7 & 75.5 & 89.6 & 590.5 \\
\hline Gediz & 70.9 & 64.3 & 56.4 & 56.9 & 38.5 & 22.9 & 14.3 & 11.5 & 19.2 & 45.1 & 67.3 & 84.7 & 552 \\
\hline İzmir & 114.8 & 104.7 & 79.3 & 46.3 & 25.7 & 8.4 & 2.3 & 1.9 & 17.7 & 49.9 & 105.8 & 130.8 & 687.6 \\
\hline Köprübașı & 0 & 0 & 0 & 0 & 0 & 0 & 0 & 0 & 0 & 0 & 0 & 0 & 0 \\
\hline Manisa & 110.7 & 106.4 & 83 & 56.1 & 32.3 & 15.5 & 5.6 & 5.5 & 16.7 & 50.2 & 97 & 129.5 & 708.5 \\
\hline Turgutlu & 62 & 68.8 & 60.4 & 46.6 & 28.5 & 9 & 3.7 & 2.6 & 14.2 & 29.9 & 70.2 & 74.2 & 470.1 \\
\hline \multicolumn{14}{|c|}{ Buharlașma (mm) } \\
\hline Akhisar & 1.9 & 1.4 & 13.5 & 106.8 & 173.2 & 237.7 & 292.1 & 270.4 & 185.9 & 101.7 & 35.7 & 5.2 & 1425.5 \\
\hline Demirci & & & & 58 & 174.7 & 234.8 & 301.8 & 273 & 180.6 & 113.2 & 38.6 & 6.1 & 1380.8 \\
\hline Gediz & 0.2 & & & 66.5 & 117.4 & 154.4 & 202.7 & 191.6 & 130.7 & 73.9 & 11.7 & 3.2 & 952.3 \\
\hline İzmir & 11.7 & 12 & 25.5 & 120.2 & 179.3 & 240.4 & 282.8 & 251 & 183.2 & 112.5 & 62.6 & 29.3 & 1510.5 \\
\hline
\end{tabular}


yanında Orta ve Așağı Gediz'de Adala, Ahmetli, Menemen, Akhisar, ve Alașehir ovaları bulunmakta ve bu ovalarda yaklașık 110000 hektarlık alana sahip sulama sistemleri bulunmaktadır (Çetinkaya ve Barbaros, 2008).

Halihazırda Devlet Su İșleri (DSi) Genel Müdürlüğü tarafından havzada birçok yatırım yapılmıștır. Bunlardan Demirköprü, Avșar ve Buldan barajları; Çömlekçi, Adala, Marmara, Emiralem, Ahmetli ve Buldan bağlamaları DSi tarafından; Akpınar, Alașehir, Sarıgöl, Adala I ve II, Gökkaya, Ahmetli, Maltepe, Menemen, Türkeli ve Emiralem sulama sistemleri ise sulama birlikleri tarafından ișletilmektedir. Havzadaki belli bașlı su yapıları sulama amaçlıdır. Demirköprü, Avșar ve Buldan baraj gölleri ve Marmara Gölü 110000 hektarlık tarımsal sulama alanını beslemektedir. Gediz Havzasında hali hazırda tarımsal su ihtiyacı genelde yüzeysel sulardan, endüstriyel ve kentsel su ihtiyaçları ise yeraltı suyundan karșılanmaktadır (Cetinkaya ve Barbaros 2008).

Gediz Havzasında mevcut suyun 161 mm/yıl) neredeyse tamamı kentsel, endüstriyel ve tarımsal su intiyacının karșılanmasında kullanılmaktadır. Mevcut yıllık yüzeysel su potansiyelinin (53 mm/yıl) yaklașık olarak \%75'i havzada sulama amaçlı tahsis edilmektedir. Sulama suyu talebi her ne kadar yıldan yıla değișse de, havza boyunca ortalama olarak 39 mm/yıl civarındadır. Bunun yanında yer altı suyundan (8 9 mm/yıl) karșılanan kentsel su ihtiyacı ise hızı nüfus artıșına bağlı olarak giderek artmaktadır (Çetinkaya ve Barbaros 2008).

\section{Referans evapotranspirasyonun hesaplanması}

Araștırmada, Gediz havzası içinde ve çevresinde bulunan toplam 14 (Manisa, İzmir, Akhisar, Demirci, Simav, Ușak, Ödemiș, Salihli, Gediz, Bergama, Balıkesir, Simav ve Afyon) meteoroloji istasyonunda günlük olarak ölçülen yaklașık son 30 yıllık veri setlerinin ortalaması kullanılmıștır.

Evapotranspirasyonun hesaplanmasında Standardize FAO Penman Montehit yöntemi kullanılmıștır. Hesaplamada elde var olan meteorolojik ölçümlerle birlikte ayrıca ilgili eșitlikler yardımıyla hesaplanan veriler kullanılmıștır. Standart edilmiș referans ET eșitliği așağıdaki gibidir;

$$
\mathrm{ET} S Z=\frac{\left(0.408 \Delta\left(\mathrm{R}_{n}-\mathrm{G}\right)+\gamma \frac{\mathrm{C}_{n}}{\mathrm{~T}+273} U_{2}(\text { ea-ea })\right.}{\Delta+\gamma\left(1+\mathrm{C} d U_{2}\right)}
$$

ETsz = standart edilmiș referans bitki su tüketimi (kIsa (ETo) ve uzun (ETr)) ( $\mathrm{mm} \mathrm{d}^{-1}$ veya $\mathrm{mm} \mathrm{h}^{-1}$ ),

Rn = Bitki yüzeyi için hesaplanmıș net radyasyon

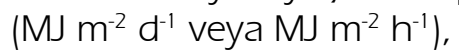

$\mathrm{G}=$ Toprak yüzeyi için toprak ısı akısı (MJ $\mathrm{m}^{-2} \mathrm{~d}^{-1}$ veya $\mathrm{MJ} \mathrm{m}^{-2} \mathrm{~h}^{-1}$ )

$\mathrm{T}=$ Ortalama günlük veya saatlik hava sıcaklığı, 1.5 - 2.5 m yükseklikte ölçülmüș $\left({ }^{\circ} \mathrm{C}\right)$,

u2 = Ortalama günlük veya saatlik rüzgar hızı, $2 \mathrm{~m}$ yükseklikte ölçülmüș $\left(\mathrm{m} \mathrm{s}^{-1}\right)$,

es=Doygun buhar basıncı, 1.5-2.5 myükseklikte ölçülmüș, (kPa), günlük hesaplamalarda en yüksek ve en düșük sıcaklıklar için hesaplanan doygun buhar basıncının ortalaması kullanılmalıdır.

ea = Ortalama gerçek buhar basıncı, 1.5 - 2.5 m yükseklikte ölçülmüș, (kPa),

$\Delta$ = Doygun buhar basıncı - sıcaklık eğrisinin eğimi, $\mathrm{kPa}{ }^{\circ} \mathrm{C}^{\mathrm{W}}$,

$$
\gamma=\text { Pisikrometrik sabite }\left(\mathrm{kPa}^{\circ} \mathrm{C}^{-1}\right) \text {, }
$$

$\mathrm{Cn}=$ Referans bitkiye ve hesaplamada esas alınana zaman dilimine göre değișen pay katsayısı,

$c d=$ Referans bitkiye ve hesaplamada esas alınana zaman dilimine göre değișen payda katsayısı.

\section{Jeoistatistiksel yöntem}

İstatistiğin uygulamalı bir dalı olan jeoistatistik, ilk defa yerbilimlerinde karșılașılan tahmin problemlerinin çözümüne yönelik olarak kullanılmıștır. Jeoistatistikte ölçüm yapılan notaların konumları ile gözlemler arası korelasyon dikkate alınır. Bu yöntemle yansız ve minimum varyanslı tahminler yapılabilmektedir (Olea, 1977, Bașkan, 2004). Ölçülen değerlerden deneysel variogram yapısı belirlenir. Jeoistatistiksel çalıșmaların temelini, bu belirlenen variogram yapısına teorik bir modelin uydurulması olușturmaktadır (Delhomme 1978, Vieira vd 1983, Bașkan, 2004). Jeoistatistiksel yöntemler, yönlü verilere uygulandığında oldukça sağlam ve güçlü sonuçlar ortaya koymaktadır.

Jeoistatistik metotları arasında en fazla tercih edilen yöntem Krigingdir. Gumiaux vd. (2003)'ın bildirdiğine göre bu metot ilk kez Matheron tarafından 1962 yılında geliștirilmiștir. Bu yöntemde hesaplamada dikkate alınan verilerin farklı katkıları göz önüne alınarak veri noktaları 
arasında enterpolasyon yapılmaktadır. Bu yöntem, bir değișkenin yeri ve çevresindeki komșu diğer veri noktalarının arasındaki enterpolasyonun optimum tahmini olarak tanımlanır (Cressie, 1990).

Çalıșmada ETo haritalarının hazırlanmasında kullanılacak yöntem olarak, Noshadi ve Sepaskhah, (2005)'in çalıșmasındaki önerileri dikkate alınmıștır. Söz konusu araștırıcılar, ETo'ın hesaplanmasına ve haritalanmasına yönelik olarak yaptıkları çalıșmada, enterpolasyon yöntemi olarak cokriging yöntemlerini; semivariogram olarak spherical modelin kullanımını iyi sonuçlar verdiğini dile getirmektedirler.

\section{BULGULAR VE TARTIȘMA}

\section{Jeoistatistiksel yöntem sonuçları}

Noshadı ve Sepaskhah, (2005)'in ETo'in hesaplanmasına da ve haritalanmasında, enterpolasyon yöntemi olarak cokriging yöntemlerini; semivariogram olarak spherical modelin kullanımını iyi sonuçlar verdiğini belirtmektedirler. Çalıșmada da söz konusu araștırıcıların önerileri dikkate alınmıș ve alanın ETo haritaları üretilmiștir. Haritaların üretilmesi sırasında kullanılan yöntemlere ilișkin olarak hesaplanan önemli temel istatistiksel parametreleri Çizelge 2'de sunulmuștur. Nisan-Eylül ayları (dahil) ve yıllık toplam değere ilișkin hazırlanana haritalar Șekil 2-8 arasında sunulmuștur.

Çizelge 2'den de görülebileceği gibi, Nisan ayında hesaplanan en yüksek ETo değeri 110.7 ve en düșük ise 77.6 mm/ay'dır. Șekil 2'den de görülebileceği gibi havzanın kuzey-doğu ve kuzeyine doğru artan yükseklikle birlikte ETo değeri azalma göstermektedir. Batı, güney ve güney-batıya doğru ETo değerleri artıș göstermektedir. Özellikle tahıl üretimi yapılan bölgelerde, yağıșın yetersiz olduğu zamanlarda,
Nisan hatta bazı dönemlerde Mayıs ayıda dahil sulama suyuna gereksinim duyulmaktadır. Söz konusu dönelerde verim ve kalitede düșüșün önlenmesi için tamamlayıcı sulamaların yapılması gerekmektedir. Üretilmekte olan bitkiler için sulama suyu gereksinimi ETo değerlerinin yetiștirilen ürüne ait bitki kat sayısı ile düzeltilerek uygulanması pratikte kolaylıklar sağlayacaktır. Böylelikle daha önce de dile getirildiği gibi hem verim ve kaliteden kayıpların olușması önlenebilir hem de kıt kaynak sulama suyundan, enerjiden ve zamandan tasarruf edilebilir.

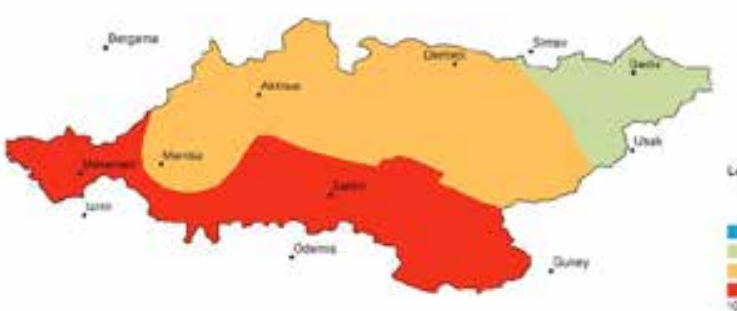

$\hat{\Lambda}$

Șekil 2. Nisan ayı ETo'ındaki değișimi

Figure 2. Change of ETo in April

Mayıs ayı ETo'ları Nisan ayı değerlerine oranla artıș göstermektedir. Çizelge 2'den de görülebileceği gibi, Mayıs ayında hesaplanan en yüksek ETo değeri 152.8 ve en düșük ise 112.2 mm/ay'dır. Șekil 3'den de görülebileceği Nisan ayındaki gibi, havzanın kuzey-doğu ve kuzeyine doğru artan yükseklikle birlikte ETo değeri azalma göstermektedir. Havzanın özellikle Menemen ovasının yer aldığı batı bölümünde ETo değerleri 150 mm'yi așmaktadır. Manisa, Salihli, Akhisar ve Demirci'nin güney bölgelerinin olduğu ve havzanın orta bölümü olarak kabul edilebilecek bölgede ise yaklașık 140 mm'nin üzerinde ETo değeri hesaplanmıștır. Bölgede üretimi yapılan bitkilerin, özellikle yağıșın yetersiz

Çizelge 2. Haritalara ilișkin bazı istatistiksel parametreler

Table 2. Values of some statistical parameters of maps

\begin{tabular}{lccccccc}
\hline Parameters & Nisan & Mayıs & Haziran & Temmuz & Ağustos & Eylül & Yıllık Toplam \\
Count & 14 & 14 & 14 & 14 & 14 & 14 & 14 \\
Min & 77.6 & 112.2 & 143.6 & 162 & 144.7 & 99.3 & 975 \\
Max & 110.7 & 152.8 & 191.1 & 227 & 212.7 & 153.5 & 1377 \\
Root Mean Square & 3.84 & 6.14 & 10.01 & 12.30 & 16.46 & 11.47 & 72.92 \\
Mean Standardized & 0.0004 & 0.012 & -0.003 & -0.02 & -0.01 & -0.04 & -0.01 \\
Root Mean Square Standardized & 0.60 & 0.65 & 0.81 & 0.79 & 0.93 & 0.94 & 0.76 \\
Average Standard Error & 6.02 & 8.68 & 12.36 & 15.30 & 17.46 & 11.68 & 9.9 \\
\hline
\end{tabular}


olduğu ve sulama suyuna gereksinim duyulduğu zamanlarda, verim ve kalitede düșüșün önlenmesi için sulamaların yapılması gerekmektedir.

Istasyonlara ait Haziran ayı ETo değerlerinin dağııımı, Nisan ve Mayıs ayları ile benzerlik göstermektedir. Çizelge 2 'den de görülebileceği gibi, Haziran ayında hesaplanan en yüksek ETo değeri 191.1 ve en düșük ise 143.6 mm/ay'dır. Șekil 4'den de görülebileceği gibi güney ve güney batı bölümünde ortalama 190 mm civarında gerçekleșirken havzanın orta bölümünde 180 mm'lere kadar yükselmektedir. Havzanın doğusunda yer alan ve havzaya ismini veren Gediz ilçesine doğru yaklașı 140 mm'ye kadar düșüș göstermektedir. Söz konusu bölgeler havzanın yüksek kesimlerini olușturmaktadır.

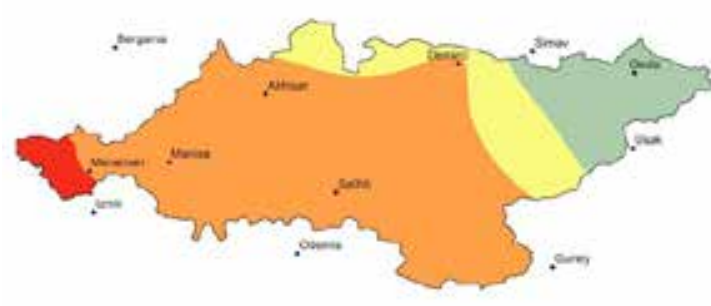

Șekil 3. Mayıs ayı ETo'ındaki değișimi

Figure 3. Change of ETo in May

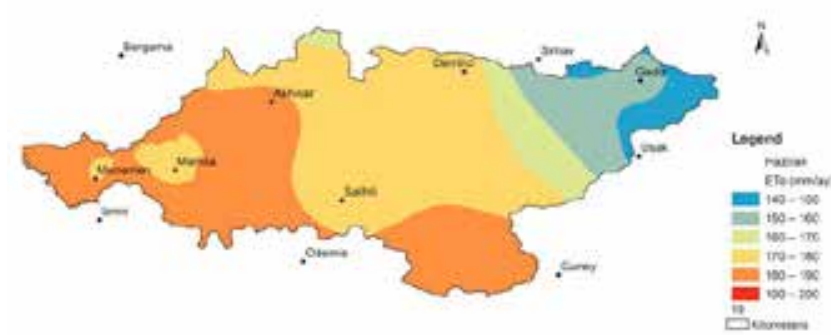

Șekil 4. Haziran ayı ETo'ındaki değișimi

Figure 4. Change of ETo in June

Temmuz ayı tüm havza için en yüksek ETo değerlerinin hesaplandığı aydır. Söz konusu ayda en yüksek ETo değeri 227 mm'dir. En düșük değer ise $162 \mathrm{~mm}$ ile havzanın doğusunda yer alan ve aynı zamanda havzanın yüksek kesimlerini olușturan Gediz ilçesi çevresinde hesaplanmıștır. Șekil 5'den de görülebileceği gibi Temmuz ayı içerisinde havzanın büyük bölümü ortalama 200 $\mathrm{mm}$ civarında ETo hesaplanmaktadır. Yine en düșük havzanın en yüksek kesiminde bulunana Gediz ilçesi çevresinde 160-170 mm civarında gerçekleșmektedir. En yüksek ETo değerleri

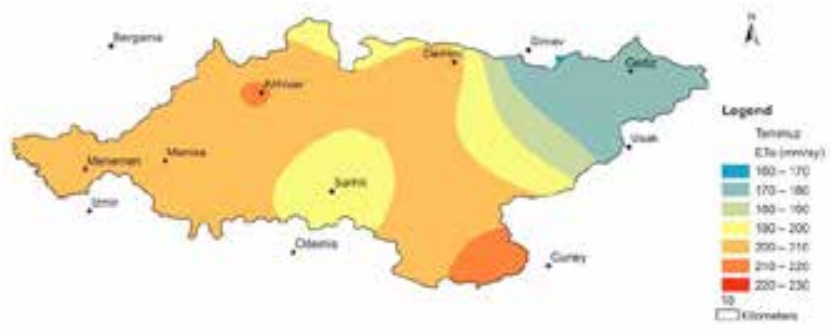

Șekil 5. Temmuz ayı ETo'ındaki değișimi

Figure 5. Change of ETO in July

Akhisar çevresinde yaklașık 210-220 mm arasında belirlenmiștir. Salihli ilçesi ve çevresinde söz konusu değerler 190-200 mm civarına gerilemektedir.

Temmuz ayındaki benzer durum Ağustos ayında da görülmektedir. Havza için hesaplanan en yüksek ETo değeri 212.7 ve en düșük ise 144.7 mm'dir. Șekil 6'dan da görülebileceği gibi havzanın büyük bölümü ortalama 180-190mm civarında ETo sergilemektedir. Yine en düșük değer havzanın en yüksek kesiminde bulunana Gediz ilçesi çevresinde 150-160 mm civarında gerçekleșmektedir. En yüksek ETo değerleri Akhisar çevresinde yaklașı 200 mm civarında belirlenmiștir. Salihli ilçesi ve çevresinde söz konusu değerler 170-180 mm civarında belirlenmiștir.

Eylül ayı için hesaplanan ETo'ların dağııımı Temmuz ve Ağustos aylarıyla benzerlik göstermektedir. Eylül ayında en yüksek ETo değeri 153.5 ve en düșük 99.3 mm'dir. Șekil 7'den de görülebileceği gibi havzanın batısında yer alan Menemen ve Akhisar'ın özellikle batı ve kuzey

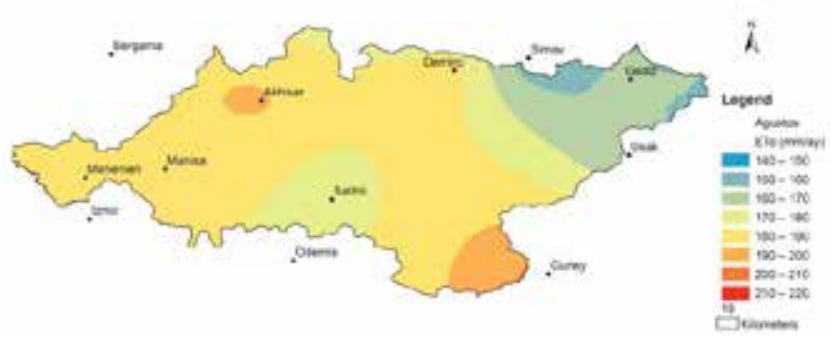

Șekil 6. Ağustos ayı ETo'ındaki değișimi

Figure 6. Change of ETo in August

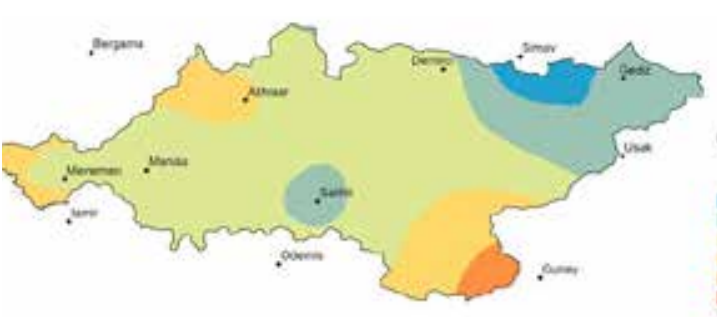

$i$

Șekil 7. Eylül ayı ETo'ındaki değișimi

Figure 7. Change of ETo in September 
batı bölümü ile havzanın güneyinde ETo değerler havza geneline göre yüksek olup yaklașıl 130-140 mm civarındadır. Yine havzanın yüksek bölgeleri olan doğu bölümünde en düșük ETo (100-120 mm arası) değerleri dağılımı görülmektedir. Havzanın büyük bölümünde aylık 120-130 mm ETo değeri dağılım göstermektedir.

Gediz havzası için hesaplanan yıllık toplam ETo değerlerinin dağııım, daha önce açıklanan Nisan, Mayıs, Haziran, Temmuz, Ağustos ve Eylül aylarında belirlenen dağılımların ortalaması șeklindedir. Gediz havzası için hesaplanan en yüksek ETo değeri 1377 mm olup havzanın batısında bulunan Menemen ilçesi çevresi ile havzanın güneyinde yer alan komșu istasyon olan Denizli ilinin Güney ilçesine doğru uzanan Alașehir ve Sarıgöl ilçeleri çevresinde olduğu görülmektedir. Havzaya ismini veren Gediz nehrinin oluștuğu ve aynı zamanda da havzanın yüksek kesiminde yer alana Gediz ilçesi çevresinde en düșük ETo değerleri dağılım göstermektedir. Manisa ve Akhisar çevreleri ile Demirci ilçesinden güneyinde kalan bölgede ETo değerleri 1200$1250 \mathrm{~mm}$ civarında gerçekleșmektedir. Salihli Ovasından kuzey güney doğrultusundan ortalama ETo değerleri 1150-1200 mm civarındadır.

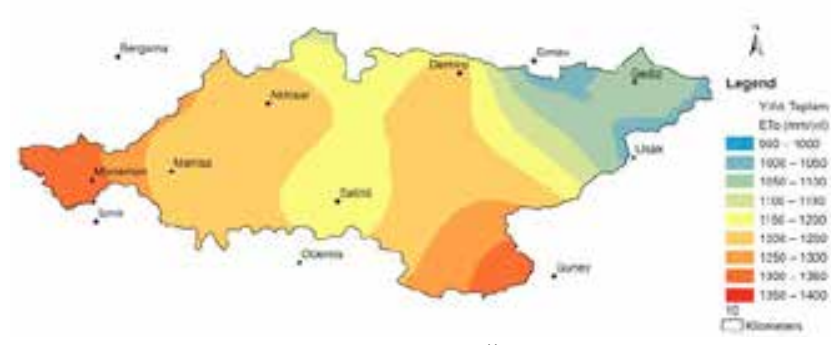

Șekil 8. Yıllık toplam ETo'ındaki değișimi

Figure 8. Change of ETO in years

\section{SONUÇLAR}

Evapotranspirasypon, kit kaynak suyun optimum șekilde kullanılmasının yanında, son yıllarda meydana gelen kuraklıklarla mücadelede dikkate alınan parametrelerin bașında gelmektedir. Ayrıca mevcut su kaynaklarının potansiyelleri dikkate alınarak sürdürülebilir șekilde değerlendirilmesi, tarımsal üretimin devamlıı̆ı açsından son derece önemlidir. Bunlara bağlı olarak yetiștiriciliği yapılan tüm ürünlerin sulama suyu intiyaçlarının saptanabilmesi ancak doğru yöntemlerle hesaplanmıș ve geçerliliği test edilmiș evapotrasnpirasyon değerleriyle mümkündür.
Evapotrasnpirasyonun ölçülmesi ve izlenmesi klasik yöntemlerde hem zaman alıc hem de maliyetli bir ișlemdir. Son yıllarda gelișen teknoloji sayesinde ölçme ve izleme yöntemleri gelișmiștir. Alansal, bölgesel, havza ölçeğinde ve hatta ülkesel boyutta referans evapotrasnpirasyon belirlenmesi ve bunların dağlım haritalarının hazırlanması pratikte sulama programlarının olușturulmasında önemli katkılar sağlamaktadır. İster arazi denemelerinden isterse güvenilirliği ispatlanmıș yöntemlerle yapılan hesaplamalar sonucunda elde edilen veriler, doğru jeoistatisitiksel yöntemlerle analiz edilip haritaların hazırlanması, gerek konu uzmanlarına gerekse üreticiler için son derece yararlı ve kullanıșlıdır. Uygun jeoistatisitik yöntemlerle yapılan evapotrasnpirasyonun haritaları daha kısa sürelerde ve daha doğru șekilde yapılabilmektedir. Eskiden kullanılan yöntemlerle bir bölgenin evapotrasnpirasyon haritalarını hazırlanmak, alanının büyüklüğüne bağlı olarak aylar hatta yıllar alabilmekteydi. Ancak son yıllarda geliștirilen yöntemler yardımıyla söz konusu haritaların hazırlanmasını veri setlerinin hazır olması durumunda birkaç dakika içinde gerçekleștirilebilmektedir. Söz konusu haritaların doğruluklarını/güvenilirliklerini belirleyen en önemli etmenlerden bir tanesi kullanılan jeoistatisitik yöntemdir. Dile getirilen yöntem, ilgili konuya ait parametrenin mekânsal bakımdan değișimini ve ilișkilendirilen diğer parametrelerle olan ilișkisini de incelemede yarar sağlamaktadır.

Referans evapotrasnpirasyonun hesaplanmasında Standardize FAO Penman Montehit yöntemi Gediz havzası için uygun ve iyi sonuçlar veren bir yöntemdir. Ayrıca, ETo haritalarının jeoistatisitiksel yöntemle hazırlanmasında da Noshadı ve Sepaskhah, (2005)'in önerdikleri gibi enterpolasyon yöntemi olarak cokriging; semivariogram olarak spherical modelin kullanımının harita hazırlamada iyi sonuçlar verdiği belirlenmiștir.

\section{KAYNAKLAR}

Ahmed S, De Marsily G (1987). Computation of geostatistical methods for estimating transmissivity using data on transmissivity and specific capacity. Water Resour. Res. 23, 1717-1737.

Anonim 2003. Tarım ve Köyisleri Bakanlıgı, Köy Hizmetleri Genel Müdürlügü, APK Dairesi Baskanlıgı Yayınları, Türkiye Toprak Su Kaynakları ve Çöllesme Raporu, Ankara. http:// www.khgm.gov.tr/kutuphane/collesme/colleme.htm. Erisim Tarihi: 13.02.2009. 
Bașkan O (2004). Gölbası yöresi topraklarının mühendislik, fiziksel özellik ilișkilerinde jeoistatistik uygulaması, Doktora Tezi, Aü, Fen Bilimleri Enstitüsü, (Basılmamıș) Ankara.

Cressie NAC (1990). The origins of kriging. Math. Geol. 22: $239-252$.

Creutin JD, Obled C (1982). Objective analyses and mapping techniques for rainfall fields: an objective comparison. Water Resour. Res. 18: 413-431.

Çetinkaya CP, Barbaros F (2008). Su Yönetimi Senaryoları \%le Gediz Nehri Yıllık Su Bütçesi Performansının Değerlendirilmesi. TMMOB 2. Su Pólitikaları Kongresi Bildirileri, TMMOB, s. 323-334. 20-22 Mart 2008, Ankara,

Delhomme JP (1978). Kriging in the Hydrosciences. Advances in Water Resources, 1 (5): 251-266.

Gumiaux C, Gapais D, Brun JP (2003). Geostatistics applied to best-fit interpolation of orientation data. Tectonophysics 376: 241- 259.

Isaaks EH, Srivastava RM (1989). An Introduction to applied geostatistics. Oxford University Press, New Yourk, p. 561

Martinez-Cob A, Cuenca RH (1992). Influence of elevation on regional evapotranspiration using multivariate geostatistics for various climatic regimes in Oregon. J. Hydrol. 136: 353-380.
Noshadi M, Sepaskhah AR (2005). Application of geostatistics for potential evapotranspiration estimation. Iranian Journal of Science \& Technology, Transactions of Civil Engineering 29 (3): 343-355

Olea RA (1977). Measuring spatial dependence with semivariograms. kansas geological survey, series on spatial analysis, No. 3, Lawrance, Kansas. p. 122

Philips DL, Dolph JD, Marks D (1992). A comparison of geostatistical procedures for spatial analysis of precipitation in mountainous terrain. Agric. For. Meteorol. 58: 119-141.

Samper FJ, Carrera J (1990). Multivariate geostatistical analysis of evapotranspirations and precipitation in mountainous terrain. Geostatistica: Applications a la hydrologia subterrancea. In: A. Martinez-Cob (ed) J. Hydrol. 174: 19-35.

Taș I, Kırnak H (2011). Yarı kurak iklim bölgelerinde bitki su tüketiminin tahmininde kullanılabilecek ampirik modeller. Adnan Menderes Üniversitesi, Ziraat Fakültesi Dergisi, 2011 ; 8(1): 57 - 66 .

Vieira SR, Hatfield JL, Nielsen DR, Biggar JW (1983). Geostatistical theory and application to variability of some agronomical properties. Hilgardia, 51 (3): 1-75, DavisCalifornia

Weber D, England E (1994). Evaluation and comparison of spatial interpolators II. Math. Geol. 26: 589-603. 